\title{
THE RENAL CLEARANCE OF PENICILLINS F, G, K, AND X IN RABBITS AND MAN ${ }^{1}$
}

\author{
BY HARRY EAGLE AND ELLIOT NEWMAN \\ WITH THE TECHNICAL ASSISTANCE OF ARLYNE D. MUSSELMAN, MARGOT ROBINSON, \\ AND MARION BIRMINGHAM \\ (From the Laboratory of Experimental Therapeutics of the U.S. Public Health Service and \\ The Johns Hopkins School of Hygiene, and the Department of Medicine of the \\ Johns Hopkins Medical School, Baltimore 5, Maryland)
}

(Received for publication February 6, 1947)

The factor which most seriously limits the therapeutic efficacy of penicillin is its rapid urinary excretion. Thus, the renal clearance of commercial penicillin in man has been found $(1,24)$ to vary between 755 and 1,120 ml. per minute, approximating the total renal plasma flow ; and when crystalline penicillin $\mathrm{G}$ or $\mathrm{X}$ is injected intramuscularly in aqueous solution at average therapeutic dosage ( $0.6 \mathrm{mgm}$. per $\mathrm{kgm}$.), approximately 60 per cent is excreted in the urine in the first hour (2 to 4). Largely because of that rapid excretion, the blood level of e.g. penicillin $G$ falls off, after its intramuscular injection in aqueous solution, at an average rate of 70 to 80 per cent each succeeding hour, or 2 to 3 per cent each minute $(4,19)$. It is apparent that even a minor decrease in the rate of renal excretion would be reflected in significantly prolonged blood levels and a correspondingly enhanced therapeutic efficacy.

There is considerable evidence that penicillin is secreted by the renal tubules, and by the same secretory mechanism as diodrast and p-aminohippuric acid. Thus, the excretion of penicillin is said to be depressed by the simultaneous administration of either of these 2 compounds in amounts sufficient to saturate the common tubular mechanism (5 to 10). Restriction of the water or salt intake (11) and the administration of benzoic acid or pitressin (12) are also reported to curtail the excretion of penicillin and to prolong the blood penicillin curve correspondingly.

Since the 4 penicillin species known to be produced by penicillium $(F, G, K$, and $X)$ vary markedly in their pharmacological behavior and bactericidal activity $(2$ to $4,13,14)$, it was of interest to determine the renal clearance of each, over a

1 Study supported in part by the Life Insurance Medical Research Fund. widely varying range of plasma concentration, and with varying rates of urine flow. As is shown in the following, in both rabbits and man penicillins $\mathrm{F}, \mathrm{G}$, and $\mathrm{X}$ were found to have a renal clearance corresponding to the total renal plasma flow. The ratio of the glomerular filtration rate, simultaneously determined with inulin or thiosulfate, to the renal clearance of penicillin did not vary significantly over a wide range of plasma concentrations and was independent of the rate of urine flow. In rabbits, the tubular secretory mechanism was found to have been saturated by serum concentrations on the order of 100 to 1,000 micrograms per $\mathrm{ml}$.

The apparently anomalous renal clearance of penicillin $\mathrm{K}$ is discussed later in the text.

At least in the case of penicillins F, G, and $\mathrm{X}$ the nature of the side chain which differentiates the several species of penicillin, and which significantly modifies their bactericidal activity, thus has no demonstrable effect on their renal clearance. Further modification in that prosthetic group may nevertheless be a promising approach to the development of penicillins with low renal clearances and correspondingly enhanced therapeutic activity.

\section{EXPERIMENTAL METHODS}

Penicillins: The purified penicillins used in these studies were generously provided by the following pharmaceutical firms :

$$
\begin{aligned}
& \text { G-Squibb (Lot CRA-214-20) } \\
& \text { F-Upjohn (Lot 175-EANW-6) } \\
& \text { K-Abbott (Lot RP 309 P2) } \\
& \text { Pfizer (Lot 5/2/46) } \\
& \text { X-Lederle (Lot CA-3242-IC) }
\end{aligned}
$$

Penicillin assay: The blood and urine concentrations were determined by a modified Rantz-Kirby (1) serial dilution technic (cf. $[4,13]$ ), using the inhibition of hemolysis by streptococci (C-203 strain of Streptococcus pyogenes) as the endpoint. The use of 5 tubes for each 
2-fold difference in concentration (i.e., $0.8,0.72,0.6,0.48$, 0.4 , etc. $\mathrm{ml}$. of the unknown specimen in a total volume of $0.8 \mathrm{ml}$.) permitted a reasonably accurate and reproducible assay.

The technic was further modified in that the assays were removed from the incubator after 6 to 9 hours, by which time hemolysis had begun, and were then allowed to remain at room temperature overnight before reading. With this technic, contaminated urine specimens could usually be assayed without preliminary filtration, since the heavy streptococcus inoculum initiated hemolysis at $37^{\circ} \mathrm{C}$. before it had been overgrown by the contaminant, and bacterial growth in the following 10 to 15 hours at room temperature was usually too slow to obscure the results.

Calculation of results: The average serum concentration over the time period represented by the successive urine samples was obtained in the usual manner by graphic interpolation (log of serum level plotted against time).

Calibration of glomerular filtration and renal plasma flow: In some of the experiments, the rate of glomerular filtration was simultaneously determined by the administration of inulin or sodium thiosulfate, given either as a single injection, or as a constant infusion following a priming dose. In some of the subjects, the renal plasma flow was determined with para-aminohippuric acid several days before or after the administration of penicillin. The methods used for the determination of inulin and para-aminohippuric acid were those suggested by Goldring and Chasis (16). Thiosulfate was determined by the method of Newman (17).

\section{EXPERIMENTAI}

Group I. Human subjects continuously infused with penicillin $F, G, K$, or $X$

The results in 6 experiments are given in detail in Table $I$ and are graphically summarized in Figures 1 to 3 .

In subject G. J., the renal clearance of penicillin $G$ averaged $525 \mathrm{ml}$. per minute. This is to be compared with a calculated renal plasma flow of $717 \mathrm{ml}$. per minute and an observed clearance for para-aminohippuric acid of $619 \mathrm{ml}$. The parallelism between the renal clearance of penicillin $G$ and the glomerular filtration rate simultaneously determined with inulin ( $c f$. last 2 columns of Table I and Figure 1), and the constancy of their ratio $(0.19$ to 0.24 , averaging 0.23 ) are particularly to be noted.

The renal clearance of penicillin $G$ in this subject was independent of the blood level and the rate of urine flow, within the experimental range. Periods in which the blood levels averaged 2.4 and 0.25 micrograms per ml. gave clearances of 498 and
$416 \mathrm{ml}$. per minute, respectively; and periods in which the urine flow was 12.5 and $2.1 \mathrm{ml}$. per minute gave penicillin clearances of 588 and $416 \mathrm{ml}$. per minute, respectively.

When the same subject was infused with penicillin X (bottom of Table I), the renal clearance averaged $652 \mathrm{ml}$. per minute, in satisfactory agreement with both the calculated renal plasma flow (717) and the observed clearance of para-aminohippuric acid (619), and 4.6 times the calculated glomerular filtration rate of $135 \mathrm{ml}$. per minute. The renal clearance was again largely independent of the absolute serum concentration and rate of urine flow. With a 10 -fold difference in serum concentration (3.6 and 0.37 microgram per $\mathrm{ml}$.), the renal clearance varied from 456 to $699 \mathrm{ml}$. per minute; and in periods in which the urine flow averaged 10.3 and $4 \mathrm{ml}$. per minute, the renal clearances averaged 787 and $722 \mathrm{ml}$., respectively.

Subject E. W. is of particular interest (Figure 1 and the second section of Table I). This subject was a woman with long-standing hypertension, in whom the urea clearance was 58 per cent of normal, and the phenolsulfaphthalein excretion was 60 per cent in 2 hours. Corresponding to the obvious impairment of renal function, the renal clearance of penicillin $G$ averaged 242 instead of the calculated value of 617 , or 40 per cent of normal. Significant also is the fact that as her blood pressure fell from $218 / 112$ to $158 / 114$ during the first 80 minutes of the experiment, the inulin clearance increased from 52 to 97 , and the penicillin clearance from 158 to 308 , indicative of an increased flow of blood to the kidney. Meanwhile, the ratio of glomerular filtration to total renal clearance remained essentially constant at the abnormally high level of 0.31. As in patient G. J., the rate of urine flow had no significant effect on renal clearance, which varied only from 276 to $230 \mathrm{ml}$. per minute as the urine flow increased from 2.0 to $7.4 \mathrm{ml}$. per minute in 5 successive experimental periods.

Penicillin F gave results essentially the same as penicillins $G$ and $X$. The renal clearances averaged 550 and $900 \mathrm{ml}$. per minute in 2 patients in whom the calculated renal plasma flow was $750 \mathrm{ml}$. per minute. The clearance was again independent of the absolute blood level and of the rate of urine flow over the entire experimental range (cf. Figure 3 and Table I).

In patient M. B., injected with penicillin F, midway through the experiment the blood flow to the kidney apparently decreased sharply for a period of approximately 40 minutes. This was manifested by a simultaneous and parallel decrease in the renal clearance of both penicillin 
TABLE I

The renal clearance of penicillins $F, G, K$ and $X$ in man

Experiments with continuous intravenous infusion at a falling rate. Most of the patients received a priming dose of $2.5 \mathrm{mgm}$. per $\mathrm{kgm}$. and the rate of infusion was slowly reduced from an initial level of $1 \mathrm{mgm}$. per $\mathrm{kgm}$. per min. to $0.16 \mathrm{mgm}$. per $\mathrm{kgm}$. per min. over a period of 2 to 3 hours. In all but 2 patients, the urine specimens were collected by catheterization.

\begin{tabular}{|c|c|c|c|c|c|c|c|c|}
\hline \multirow{2}{*}{$\begin{array}{l}\text { Peni- } \\
\text { cillin } \\
\text { species }\end{array}$} & \multirow{2}{*}{ Subject } & \multicolumn{2}{|c|}{ Urine collection } & \multirow{2}{*}{$\begin{array}{l}\text { Urine } \\
\text { penicillin }\end{array}$} & \multirow{2}{*}{$\begin{array}{l}\text { Average } \\
\text { serum } \\
\text { penicillin }\end{array}$} & \multirow{2}{*}{$\begin{array}{c}\text { Renal } \\
\text { clearance } \\
\text { of penicillin }\end{array}$} & \multirow{2}{*}{$\begin{array}{l}\text { Glomerular } \\
\text { filtration rate. } \\
\text { experimentally } \\
\text { detd. with inulin } \\
\text { or thiosulfate }\end{array}$} & \multirow{2}{*}{$\begin{array}{l}\text { Ratio of } \\
\text { glomerular } \\
\text { filtration to } \\
\text { penicillin } \\
\text { clearance }\end{array}$} \\
\hline & & $\begin{array}{l}\text { Time } \\
\text { period }\end{array}$ & $\begin{array}{l}\text { Urine } \\
\text { flow }\end{array}$ & & & & & \\
\hline \multirow{6}{*}{$F^{* *}$} & \multirow[t]{3}{*}{$\begin{array}{l}\text { H. G. } \\
\text { Wt. }=75 \mathrm{kgm} . \\
\text { Ht. }=70 \mathrm{in} . \\
\text { Surface area }= \\
1.89 \text { sq. } \mathrm{m} .\end{array}$} & \multirow[t]{3}{*}{$\begin{array}{c}\text { minutes } \\
30-50 \\
50-74 \\
74-97 \\
97-114 \\
114-130 \\
130-142\end{array}$} & \multirow[t]{3}{*}{$\begin{array}{c}\text { ml. per min. } \\
9.6 \\
10.2 \\
6.1 \\
9.7 \\
11.5 \\
15.7\end{array}$} & \multirow[t]{3}{*}{$\begin{array}{c}\text { ug. per min. } \\
550 \\
221 \\
222 \\
156 \\
111 \\
165\end{array}$} & $\begin{array}{l}\text { ug. per ml. } \\
0.77 \\
0.53 \\
0.41 \\
0.29 \\
0.26 \\
0.25\end{array}$ & $\begin{array}{l}\text { ml. per min. } \\
714 \\
417 \\
541 \\
540 \\
426 \\
660\end{array}$ & $\begin{array}{c}\text { ml. per min. } \\
142 \\
\text { (calcd. from } \\
\text { surface area) }\end{array}$ & $\begin{array}{l}0.20 \\
0.34 \\
0.26 \\
0.26 \\
0.33 \\
0.22\end{array}$ \\
\hline & & & & & \multicolumn{2}{|c|}{$\begin{array}{l}\text { Experimental } \\
\text { averages }\end{array} 550$} & & 0.26 \\
\hline & & & & & \multicolumn{2}{|c|}{$\begin{array}{l}\text { Calculated } \\
\text { from surface } \\
\text { area }\end{array}$} & 142 & \\
\hline & \multirow[t]{3}{*}{$\begin{array}{c}\text { M. B. } \\
\text { Wt. }=75.5 \mathrm{kgm} . \\
\text { Ht. }=68 \mathrm{in} . \\
\text { Surface area }= \\
1.89 \text { sq. } \mathrm{m} .\end{array}$} & \multirow[t]{3}{*}{$\begin{array}{c}19-38 \\
38-56 \\
56-79 \\
79-98 \\
98-118 \\
118-137 \\
137-157\end{array}$} & \multirow[t]{3}{*}{$\begin{array}{l}0.8 \\
1.4 \\
6.7 \\
4.4 \\
0.9 \\
2.9 \\
7.5\end{array}$} & \multirow[t]{3}{*}{$\begin{array}{r}540 \\
300 \\
227 \\
55 \\
32 \\
55 \\
44\end{array}$} & $\begin{array}{l}0.6 \\
0.32 \\
0.21 \\
0.15 \\
0.11 \\
0.074 \\
0.052\end{array}$ & $\begin{array}{r}900 \\
937 \\
1080 \\
365 \\
291 \\
737 \\
850\end{array}$ & $\begin{array}{l}121 \\
186 \\
216 \\
116 \\
100 \\
137\end{array}$ & $\begin{array}{l}0.14 \\
0.20 \\
0.20 \\
0.32 \\
0.34 \\
0.18\end{array}$ \\
\hline & & & & & \multicolumn{2}{|c|}{$\begin{array}{l}\text { Experimental } \\
\text { averages }\end{array} 900^{*}$} & $165^{*}$ & 0.18 \\
\hline & & & & & \multicolumn{2}{|c|}{$\begin{array}{c}\text { Calculated } \\
\text { from surface } \\
\text { area }\end{array}$} & 142 & \\
\hline \multirow{7}{*}{$\mathbf{G}$} & \multirow[t]{4}{*}{$\begin{array}{c}\text { G. J. } \\
\text { Wt. }=65 \mathrm{kgm} . \\
\text { Ht. }=69 \frac{1}{2} \mathrm{in} . \\
\text { Surface area }= \\
1.78 \mathrm{sq} . \mathrm{m} .\end{array}$} & \multirow[t]{4}{*}{$\begin{array}{c}24-44 \\
44-63 \\
63-84 \\
84-104 \\
104-125 \\
125-144 \\
144-163 \\
163-183 \\
183-203\end{array}$} & \multirow[t]{4}{*}{$\begin{array}{r}7.9 \\
9.1 \\
12.5 \\
8.5 \\
3.4 \\
4.6 \\
2.3 \\
2.4 \\
2.1\end{array}$} & \multirow[t]{4}{*}{$\begin{array}{r}1195 \\
790 \\
646 \\
437 \\
381 \\
274 \\
181 \\
146 \\
104\end{array}$} & $\begin{array}{l}2.4 \\
1.4 \\
1.1 \\
0.82 \\
0.56 \\
0.48 \\
0.41 \\
0.335 \\
0.25\end{array}$ & $\begin{array}{l}498 \\
564 \\
588 \\
533 \\
670 \\
571 \\
441 \\
436 \\
416\end{array}$ & $\begin{array}{l}104 \\
123 \\
131 \\
118 \\
130 \\
134\end{array}$ & $\begin{array}{l}0.21 \\
0.22 \\
0.22 \\
0.22 \\
0.19 \\
0.24\end{array}$ \\
\hline & & & & & \multicolumn{2}{|c|}{$\begin{array}{c}\text { Experimental } \\
\text { averages }\end{array} 525$} & 123 & 0.23 \\
\hline & & & & & \multicolumn{2}{|c|}{$\begin{array}{l}\text { Calculated } \\
\text { from surface } \\
\text { area }\end{array}$} & 135 & 0.19 \\
\hline & & & & & \multicolumn{2}{|c|}{$\begin{array}{l}\text { PAHA } \\
\text { clearance }\end{array}$} & & \\
\hline & $\begin{array}{l}\text { E. W. } \\
\text { Wt. }=78 \mathrm{kgm} . \\
\text { Ht. }=63 \mathrm{in} . \\
\text { Surface area }= \\
1.8 \text { sq. m. }\end{array}$ & \multirow[t]{3}{*}{$\begin{array}{r}34-55 \dagger \\
55-74 \\
74-95 \ddagger \\
95-114 \\
114-134 \\
134-155 \\
155-174 \\
174-194\end{array}$} & \multirow[t]{3}{*}{$\begin{array}{l}3.2 \\
2.0 \\
3.4 \\
4.9 \\
6.7 \\
7.4 \\
5.2 \\
3.0\end{array}$} & \multirow[t]{3}{*}{$\begin{array}{r}1438 \\
1516 \\
1200 \\
787 \\
556 \\
387 \\
281 \\
198\end{array}$} & $\begin{array}{l}9.1 \\
5.5 \\
3.9 \\
2.9 \\
2.25 \\
1.68 \\
1.2 \\
0.93\end{array}$ & $\begin{array}{l}158 \\
276 \\
308 \\
271 \\
247 \\
230 \\
234 \\
213\end{array}$ & $\begin{array}{l}52 \\
76 \\
97\end{array}$ & $\begin{array}{l}0.33 \\
0.27 \\
0.31\end{array}$ \\
\hline & \multirow{2}{*}{$\begin{array}{l}\text { Urea clearance }= \\
50 \text { per cent of } \\
\text { normal } \\
\text { Phenolsulfonphthal- } \\
\text { ein }=60 \text { per cent } \\
\text { in } 2 \mathrm{hrs} \text {. }\end{array}$} & & & & \multicolumn{2}{|c|}{$\begin{array}{c}\text { Experimental } \\
\text { averages }\end{array} 242$} & 75 & 0.31 \\
\hline & & & & & $\begin{array}{c}\text { Calculat } \\
\text { from surf } \\
\text { area }\end{array}$ & 617 & 128 & 0.20 \\
\hline
\end{tabular}


TABLE I-Continued

\begin{tabular}{|c|c|c|c|c|c|c|c|c|}
\hline \multirow{2}{*}{$\begin{array}{l}\text { Peni- } \\
\text { cillin } \\
\text { species }\end{array}$} & \multirow{2}{*}{ Subject } & \multicolumn{2}{|c|}{ Urine collection } & \multirow{2}{*}{$\begin{array}{c}\text { Urine } \\
\text { penicillin }\end{array}$} & \multirow{2}{*}{$\begin{array}{c}\text { Average } \\
\text { serum } \\
\text { penicillin }\end{array}$} & \multirow{2}{*}{$\begin{array}{c}\text { Renal } \\
\text { clearance } \\
\text { of penicillin }\end{array}$} & \multirow{2}{*}{$\begin{array}{l}\text { Glomerular } \\
\text { filtration rate, } \\
\text { experimentally } \\
\text { detd. with inulin } \\
\text { or thiosulfate }\end{array}$} & \multirow{2}{*}{$\begin{array}{c}\text { Ratio of } \\
\text { glomerular } \\
\text { filtration to } \\
\text { penicillin } \\
\text { clearance }\end{array}$} \\
\hline & & $\begin{array}{c}\text { Time } \\
\text { period }\end{array}$ & $\begin{array}{l}\text { Urine } \\
\text { flow }\end{array}$ & & & & & \\
\hline \multirow{6}{*}{$\mathbf{K}$} & \multirow[t]{3}{*}{$\begin{array}{l}\text { E. P. } \\
\text { Wt. }=94 \mathrm{kgm} . \\
\text { Ht. }=70 \mathrm{in} . \\
\text { Surface area }= \\
2.11 \text { sq. } \mathrm{m} .\end{array}$} & \multirow[t]{3}{*}{$\begin{array}{c}\text { minutes } \\
35-53 \\
53-70 \\
70-96 \\
96-112 \\
112-140 \\
140-161 \\
161-180 \\
180-200 \\
200-219\end{array}$} & \multirow[t]{3}{*}{$\begin{array}{c}\text { ml. per min. } \\
9.5 \\
2.7 \\
1.4 \\
6.0 \\
4.4 \\
2.3 \\
0.8 \\
1.1 \\
?\end{array}$} & \multirow[t]{3}{*}{$\begin{array}{l}\text { Mg. per min. } \\
983 \\
433 \\
176 \\
418 \\
309 \\
152 \\
64 \\
63 \\
45\end{array}$} & $\begin{array}{l}\text { Mg. per ml. } \\
2.6 \\
2.1 \\
1.6 \\
1.1 \\
0.89 \\
0.63 \\
0.41 \\
0.27 \\
0.11\end{array}$ & $\begin{array}{c}\text { ml. per min. } \\
378 \\
206 \\
110 \\
380 \\
348 \\
241 \\
151 \\
233 \\
406\end{array}$ & $\begin{array}{c}160 \\
\text { (calcd. from } \\
\text { surface area) }\end{array}$ & 0.60 \\
\hline & & & & & \multicolumn{2}{|c|}{$\begin{array}{l}\text { Experimental } \\
\text { averages }\end{array} 272$} & & 0.60 \\
\hline & & & & & \multicolumn{2}{|c|}{$\begin{array}{c}\text { Calculated } \\
\text { from surface } \\
\text { area }\end{array}$} & 160 & \\
\hline & \multirow[t]{3}{*}{$\begin{array}{c}\text { W. J. } \\
\text { Wt. }=57 \mathrm{kgm} . \\
\text { Ht. }=66 \mathrm{in} . \\
\text { Surface area }= \\
1.62 \text { sq. } \mathrm{m} .\end{array}$} & \multirow[t]{3}{*}{$\begin{array}{c}25-67 \\
67-86 \\
86-108 \\
108-129 \\
129-153 \\
153-178 \\
178-197 \\
197-224 \\
224-243\end{array}$} & \multirow[t]{3}{*}{$\begin{array}{l}2.4 \\
2.3 \\
5.7 \\
5.0 \\
4.0 \\
4.4 \\
7.8 \\
4.6 \\
2.6\end{array}$} & \multirow[t]{3}{*}{$\begin{array}{r}481 \\
483 \\
510 \\
414 \\
326 \\
179 \\
172 \\
116 \\
37\end{array}$} & $\begin{array}{l}2.55 \\
2.0 \\
1.65 \\
1.22 \\
0.90 \\
0.69 \\
0.56 \\
0.41 \\
0.29\end{array}$ & $\begin{array}{l}189 \\
241 \\
309 \\
340 \\
362 \\
260 \\
307 \\
283 \\
128\end{array}$ & $\begin{array}{r}74 \\
71 \\
112 \\
115 \\
111 \\
108 \\
143 \\
108 \\
68\end{array}$ & $\begin{array}{l}0.39 \\
0.29 \\
0.36 \\
0.34 \\
0.31 \\
0.41 \\
0.47 \\
0.38 \\
0.53\end{array}$ \\
\hline & & & & & \multicolumn{2}{|c|}{$\begin{array}{l}\text { Experimental } \\
\text { averages }\end{array} 269$} & 101 & 0.39 \\
\hline & & & & & \multicolumn{2}{|c|}{$\begin{array}{l}\text { Calculated } \\
\text { from surface } 665 \\
\text { area }\end{array}$} & 125 & 0.20 \\
\hline \multirow{3}{*}{$\mathbf{X}$} & \multirow[t]{3}{*}{$\begin{array}{l}\text { G. J. } \\
\text { Wt. }=65 \mathrm{kgm} . \\
\text { Ht. }=69 \frac{1}{2} \mathrm{in} . \\
\text { Surface area }= \\
1.78 \text { sq. } \mathrm{m} .\end{array}$} & \multirow[t]{3}{*}{$\begin{array}{c}24-41 \\
41-61 \\
61-82 \\
82-101 \\
101-117 \\
117-140 \\
140-162 \\
162-179 \\
179-201\end{array}$} & \multirow[t]{3}{*}{$\left.\begin{array}{r}9.8 \\
4.0 \\
5.0 \\
10.3 \\
8.5 \\
4.8 \\
4.3 \\
5.4 \\
5.6\end{array}\right\} 6.7$} & \multirow[t]{3}{*}{$\left.\begin{array}{r}1641 \\
1444 \\
1070 \\
1062 \\
1045 \\
307 \\
208 \\
415\end{array}\right\} 602$} & $\left.\begin{array}{l}3.6 \\
2.0 \\
1.6 \\
1.35 \\
1.15 \\
0.84 \\
0.55 \\
0.47 \\
0.37\end{array}\right\} 0.96$ & $\left.\begin{array}{l}456 \\
722 \\
670 \\
787 \\
900 \\
365 \\
380 \\
883 \\
699\end{array}\right\} 527$ & $\begin{array}{c}135 \\
\text { (calcd. from } \\
\text { surface area) }\end{array}$ & 0.19 \\
\hline & & & & & $\begin{array}{l}\text { Experimental } \\
\text { averages }\end{array}$ & 652 & & 0.22 \\
\hline & & & & & $\begin{array}{c}\begin{array}{c}\text { Calculated } \\
\text { from surface } \\
\text { area }\end{array} \\
\text { PAHA } \\
\begin{array}{c}\text { clearance } \\
\text { (detd.) }\end{array}\end{array}$ & 619 & 135 & 0.20 \\
\hline
\end{tabular}

* Two periods of obviously decreased renal plasma flow were not included in calculating averages.

** Because of the small amounts of penicillin $F$ available, the dosage in these 2 patients was approximately half that used in the experiments with $G, K$, and $X$

† Blood pressure 218/112.

$\ddagger$ Blood pressure 158/114.

and thiosulfate and a significant increase in the ratio of glomerular filtration to total renal clearance. All 3 values returned to normal levels in the last 2 experimental time periods.
Contrasting with the values obtained for the clearance of penicillin $\mathrm{G}$ and $\mathrm{X}$, the renal clearance of penicillin $\mathrm{K}$ in 2 normal subjects averaged 272 

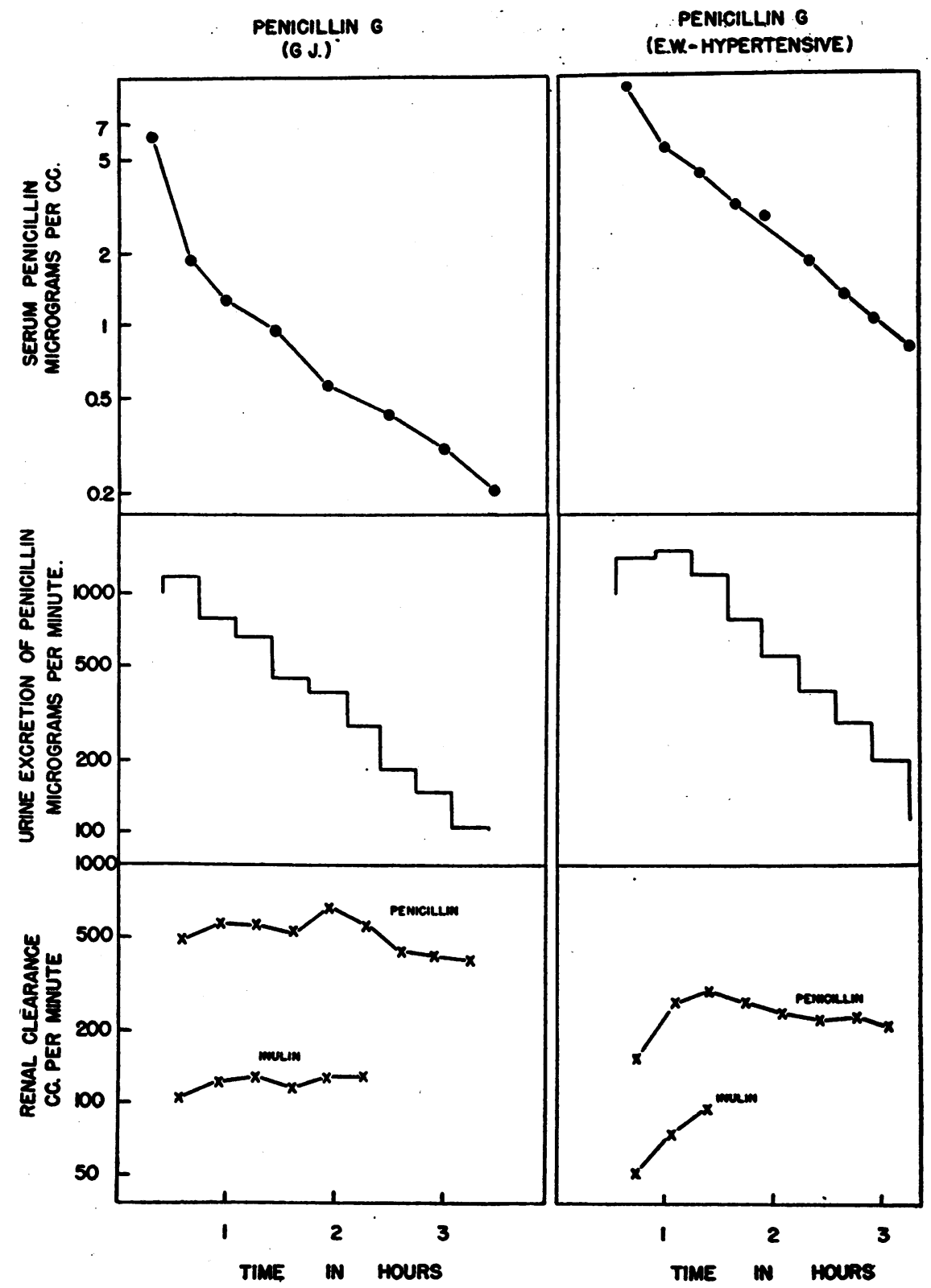

Fig. 1. The Blood Level, Urine Excretion and Renal Clearance of Penicillin G in Subjects G. J. ANd E. W.

Continuous intravenous infusion at a falling rate (After data of Table I).

and $269 \mathrm{ml}$. per minute. Within each experiment, however, the results in individual time periods varied widely, the renal clearances varying from 110 to 406 in one subject, and from 128 to 362 in the other. These variations had no demonstrable - relationship to either the blood level or rate of urine flow. In these 2 subjects, the calculated renal plasma flow was 850 and $665 \mathrm{ml}$. per minute, 3 and 2.5 times greater than the clearance of penicillin $\mathrm{K}$. The low values for the renal clearance of penicillin $\mathrm{K}$, which were confirmed in the larger group of patients discussed in the following section, are significant in relation to the low urine recovery of that penicillin species as compared with that of penicillins $\mathrm{F}, \mathrm{G}$, or $\mathrm{X}$ ( $c f$. page 914 ). 
Group II. The renal clearance of penicillins $G, K$ and $X$ in human subjects receiving a single intravenous or intramuscular injection of an aqueous solution

The determination of the renal clearance of penicillin in subjects receiving a single injection of the aqueous solution was far less accurate than the continuous infusion technic used in the experiments of the previous section. The rapidly falling blood level made the "average" value over a given time period of dubious quantitative significance, while a relatively small amount of residual urine in patients who voided voluntarily, or incomplete bladder washing in patients who were catheterized, introduced a large error in the following sample. Despite these limitations, it is clear from the data of Table II that the renal clearance of penicillins $\mathrm{G}$ and $\mathrm{X}$ generally approximated the total renal

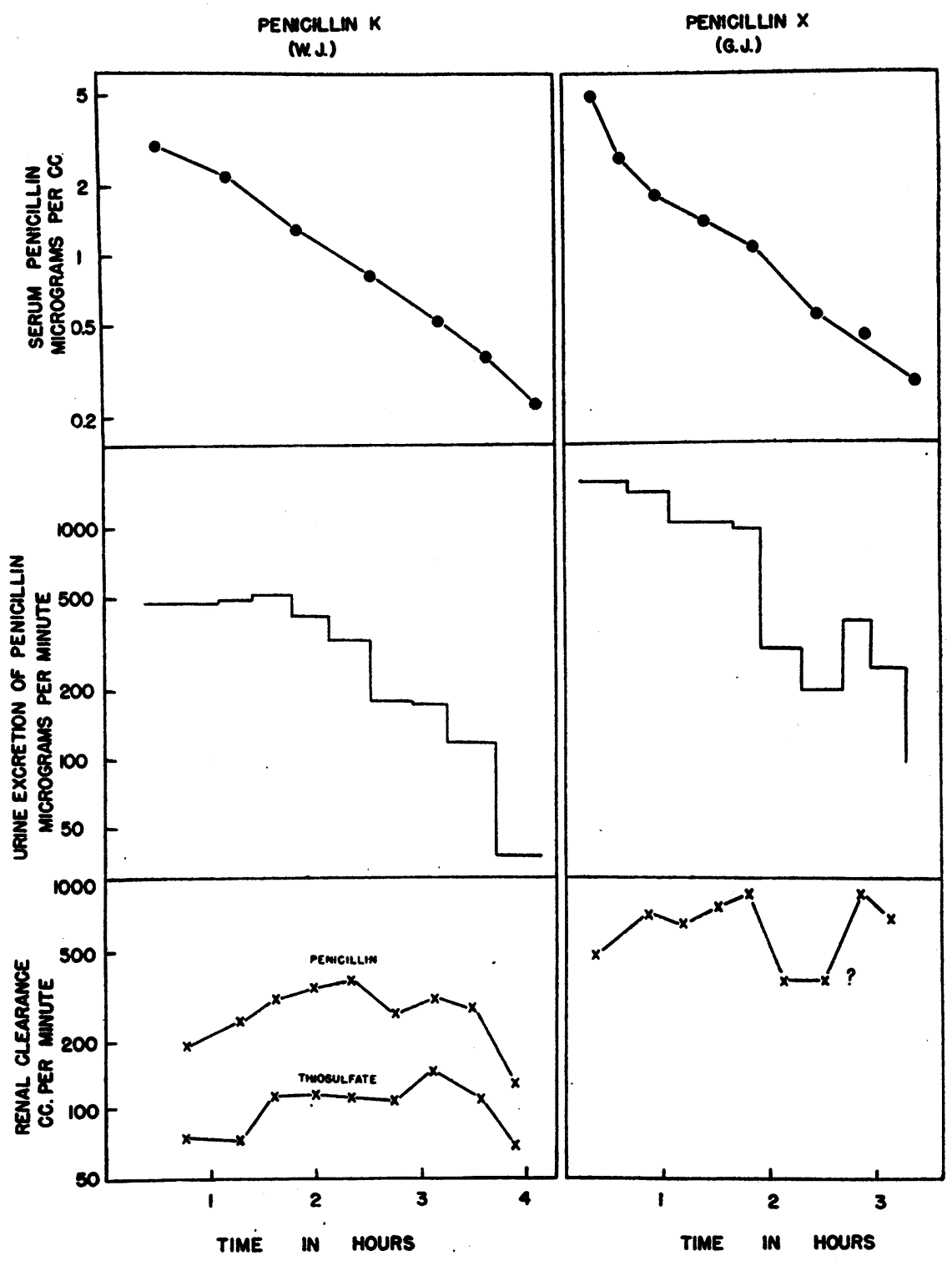

Fig. 2. The Blood Level, Urine Excretion and Renal Clearance of Penictuling K ANd X In SUbJects W. J. ANd G. J.

Continuous intravenous infusion at a falling rate (After data of Table I). 


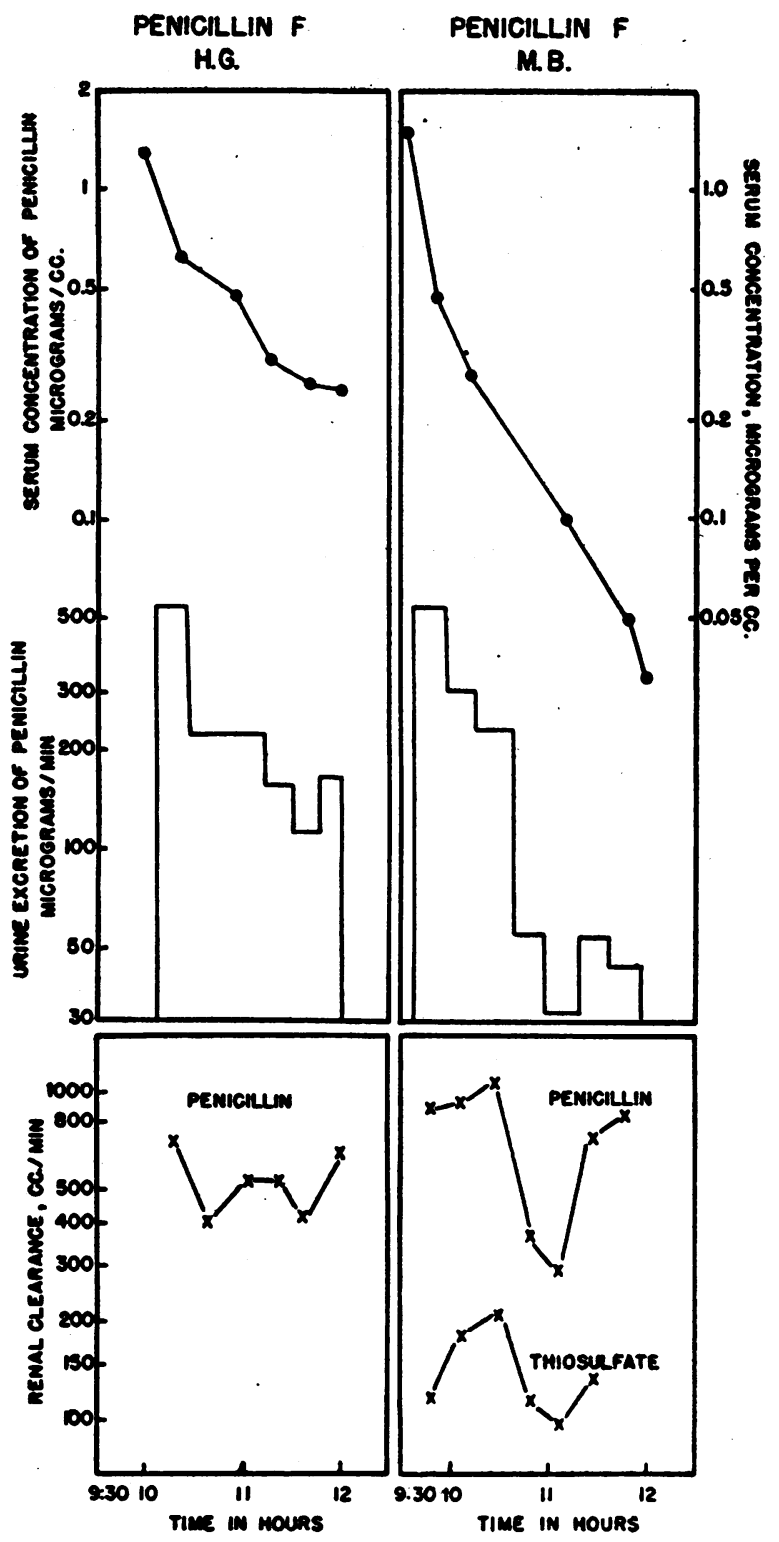

Fig. 3. The Blood Level, Urine Excretion and Renal Clearance of Penicillin F in Subjects $H$. G. AND M. B.

Continuous intravenous infusion at a falling rate (After data of Table I).

plasma flow and averaged 4 to 6 times the glomerular filtration rate.

Patient W. B., an apparent exception, was a hypertensive with a blood pressure of $210 / 135$. The penicillin clearance of $G$ in this patient was considerably less than the calculated normal renal blood flow, and the results in successive time periods were highly variable. However, the ratio of the glomerular filtration rate, experimentally determined with inulin, to the total renal clearance of penicillin was fairly constant, averaging 0.23 . The low average clearance in this patient is probably attributable to renal damage associated with long-standing hypertension, and the variability in successive periods can probably be related to the patient's apprehensiveness and incomplete voiding.

Penicillin $\mathrm{K}$ again gave results differing from those obtained with penicillins $G$ and $X$. In the 5 patients studied, the observed renal clearance of $\mathrm{K}$ averaged $0.3,0.2,0.9,0.5$ and 0.25 of the calculated renal plasma flow. It is particularly to be noted that of these 5 patients, one (D.), when tested with $\mathrm{G}$, gave a normal clearance of $850 \mathrm{ml}$. per minute, 4 times the value obtained with $K$; and a second patient ( J. W.), who gave an average clearance of $165 \mathrm{ml}$. per minute with penicillin $\mathrm{K}$, gave clearances of 600 and $1010 \mathrm{ml}$. per minute when tested with $\mathrm{X}$.

Group III. The renal clearance of penicillin $G$ in in man after its injection as a suspension in peanut oil and beeswax

In 2 patients, the renal clearance of penicillin $G$ was determined after its injection as a finely divided suspension of the potassium salt in peanut oil and 4.8 per cent beeswax (Romansky formula [15]). The pfolonged and slowly falling blood levels obtained with this preparation proved admirably suited to the study of renal clearances. In 2 such experiments, summarized in Table III, the average renal clearances were 687 and $471 \mathrm{ml}$. per minute, to be compared with the calculated renal plasma flows of 796 and 632 . These clearances were 4.2 and 3.3 times the glomerular filtration rate as determined with sodium thiosulfate.

\section{Group IV. The renal clearance of penicillin in rabbits}

The results obtained in rabbits injected intramuscularly with the crystalline penicillins are summarized in Table IV. The renal clearance of penicillins $F, G$, and $X$, studied in a total of 17 rabbits which received 0.35 to $60 \mathrm{mgm}$. per $\mathrm{kgm}$., varied from 18 to 100 . In 4 rabbits receiving penicillin $F$, the renal clearance averaged $32 \mathrm{ml}$. per minute ( 15 to $46 \mathrm{ml}$. per minute), in 8 rabbits receiving penicillin $\mathrm{G}$ at dosages of 0.6 to $60 \mathrm{mgm}$. per kgm. the average clearance was $59 \mathrm{ml}$. per minute (17 to $111 \mathrm{ml}$. per minute), and in $5 \mathrm{rab}-$ bits receiving penicillin $\mathrm{X}$ the average clearance 
was $36 \mathrm{ml}$. per minute ( 23 to $54 \mathrm{ml}$. per minute). These results are to be compared with a reported (18) renal plasma flow in rabbits of 1.5 to $4.8 \mathrm{ml}$. per minute per gram kidney, or a range of 24 to $77 \mathrm{ml}$. per minute in rabbits with a total kidney weight of 16 grams.

One can only speculate as to the degree to which the technical manipulations of repeated catheterization and cardiac punctures affected the blood flow to the kidney, and contributed to the discrep- ant results sometimes obtained in successive time periods in the same animal. In most of the experiments the renal clearance of penicillin probably approximated the renal plasma flow; while the significantly lower values sometimes obtained may reflect a decreased blood flow to the kidney under the conditions of the experiment.

Five rabbits were injected with penicillin $\mathrm{K}$ at $0.6 \mathrm{mgm}$. per $\mathrm{kgm}$. However, the speed with which the blood levels fell and the short periods of

TABLE II

The renal clearance of penicillins $G, K$ and $X$ in man

Single intramuscular or intravenous injection. All urine specimens collected by spontaneous voiding, and not by catheterization.

\begin{tabular}{|c|c|c|c|c|c|c|c|c|c|c|}
\hline \multirow[b]{2}{*}{$\begin{array}{c}\text { Peni- } \\
\text { cillin } \\
\text { species }\end{array}$} & \multirow[b]{2}{*}{ Subject } & \multirow[b]{2}{*}{$\begin{array}{c}\text { Time } \\
\text { period }\end{array}$} & \multirow[b]{2}{*}{$\begin{array}{l}\text { Urine } \\
\text { flow }\end{array}$} & \multirow[b]{2}{*}{$\begin{array}{l}\text { Urine } \\
\text { peni- } \\
\text { cillin }\end{array}$} & \multirow[b]{2}{*}{$\begin{array}{l}\text { Average } \\
\text { serum } \\
\text { penicillin }\end{array}$} & \multicolumn{2}{|c|}{$\begin{array}{l}\text { Renal clearance of } \\
\text { penicillin }\end{array}$} & \multicolumn{2}{|c|}{$\begin{array}{l}\text { Rate of glomerular } \\
\text { filtration }\end{array}$} & \multirow{2}{*}{$\begin{array}{l}\text { Ratio of } \\
\text { glomerular } \\
\text { filtration } \\
\text { to peni- } \\
\text { cillin- } \\
\text { clearance }\end{array}$} \\
\hline & & & & & & $\begin{array}{l}\text { Experi- } \\
\text { mental } \\
\quad \text { (Aver.) }\end{array}$ & $\begin{array}{l}\text { Calcu- } \\
\text { lated } \\
\text { from } \\
\text { surface } \\
\text { area }\end{array}$ & $\begin{array}{c}\text { Experi- } \\
\text { mentally } \\
\text { detd. } \\
\text { with } \\
\text { inulin }\end{array}$ & $\begin{array}{l}\text { Calcu- } \\
\text { lated } \\
\text { from } \\
\text { surface } \\
\text { area }\end{array}$ & \\
\hline \multirow{2}{*}{ G } & $\begin{array}{c}\text { W. B. (hypertension) } \\
\text { Wt. }=73 \mathrm{kgm} . \\
\text { Ht. }=67 \frac{3}{4} \text { in. } \\
\text { Surface area }= \\
1.85 \text { sq. } \mathrm{m} .\end{array}$ & $\begin{array}{l}\text { hours } \\
\frac{1}{4}-\frac{1}{2} \\
\frac{1}{2}-1 \\
1-2 \\
\end{array}$ & $\begin{array}{c}\text { ml.per } \\
\text { min. } \\
7.1 \\
9.3 \\
6.2 \\
\end{array}$ & $\begin{array}{c}\text { Mg. per } \\
\text { min. } \\
\\
704 \\
234 \\
67\end{array}$ & $\begin{array}{c}\begin{array}{c}\text { ug. per } \\
\text { ml. }\end{array} \\
1.45 \\
0.76 \\
0.31\end{array}$ & $\begin{array}{l}486 \\
308(335) \\
216\end{array}$ & 745 & $\begin{array}{l}95 \\
84 \\
49\end{array}$ & 127 & $\begin{array}{l}0.19 \\
0.27 \\
0.23\end{array}$ \\
\hline & $\begin{array}{c}\text { D. } \\
\text { Wt. }=79 \mathrm{kgm} . \\
\text { Ht. }=75 \mathrm{in} . \\
\text { Surface area }= \\
2.06 \text { sq. } \mathrm{m} .\end{array}$ & $0-1 \frac{1}{2}$ & & 441 & 0.52 & 850 & 822 & & 150 & 0.18 \\
\hline \multirow{5}{*}{$\mathbf{K}$} & $\begin{array}{l}\text { W. B. } \\
\text { Wt. }=73 \mathrm{kgm} . \\
\text { Ht. }=67 \text { in. } \\
\text { Surface area }= \\
1.85 \text { sq. } \mathrm{m} .\end{array}$ & $\begin{array}{l}\frac{1}{4}-\frac{1}{2} \\
\frac{1}{2}-1 \\
1-2\end{array}$ & $\begin{array}{l}7.1 \\
9.3 \\
6.2\end{array}$ & $\begin{array}{c}408 \\
204 \\
89.6\end{array}$ & $\begin{array}{l}2.60 \pm \\
1.10 \\
0.27\end{array}$ & $\begin{array}{l}157 \\
185(225) \\
332\end{array}$ & 745 & $\begin{array}{l}98 \\
92 \\
90 \\
\end{array}$ & 127 & $\begin{array}{l}0.62 \\
0.41 \\
0.27 \\
\end{array}$ \\
\hline & $\begin{array}{c}\text { D. } \\
\text { Wt. }=79 \mathrm{kgm} . \\
\text { Ht. }=75 \mathrm{in.} \\
\text { Surface area }= \\
2.06 \mathrm{sq} . \mathrm{m} .\end{array}$ & $0-1$ & & 90 & 0.48 & 188 & 822 & & 150 & 0.80 \\
\hline & $\begin{array}{l}\mathrm{H} . \\
\mathrm{Wt} .=57.3 \mathrm{kgm} . \\
\text { Ht. }=70 \frac{1}{2} \mathrm{in} . \\
\text { Surface area }=\end{array}$ & $\frac{1}{1}-\frac{1}{2}$ & 5.9 & 188 & 0.30 & 627 & 685 & 124 & 129 & 0.20 \\
\hline & $\begin{array}{l}\text { L. B. } \\
\text { Wt. }=61 \frac{1}{2} \mathrm{kgm} . \\
\text { Ht. }=66 \frac{1}{2} \text { in. } \\
\text { Surface area }= \\
1.69 \text { sq. } \mathrm{m} .\end{array}$ & $0-\frac{1}{2}$ & & 150 & 0.40 & 375 & 675 & & 127 & 0.34 \\
\hline & $\begin{array}{l}\mathrm{J} . \mathrm{W} . \\
\text { Wt. }=60.5 \mathrm{kgm} . \\
\text { Ht. }=67 \mathrm{in} . \\
\text { Surface area }= \\
1.68 \mathrm{sq} . \mathrm{m} .\end{array}$ & $\begin{array}{l}0-\frac{1}{2} \\
\frac{3}{3-1} \\
1-2\end{array}$ & & $\begin{array}{l}116 \\
69 \\
18.6\end{array}$ & $\begin{array}{l}0.84 \\
0.46 \\
0.09\end{array}$ & $\begin{array}{l}138 \\
150(165) \\
207\end{array}$ & 670 & & 126 & 0.76 \\
\hline
\end{tabular}


TABLE II-Continued

\begin{tabular}{|c|c|c|c|c|c|c|c|c|c|c|}
\hline \multirow[b]{2}{*}{$\begin{array}{c}\text { Peni- } \\
\text { cillin } \\
\text { species }\end{array}$} & \multirow[b]{2}{*}{ Subject } & \multirow[b]{2}{*}{$\begin{array}{l}\text { Time } \\
\text { period }\end{array}$} & \multirow[b]{2}{*}{$\begin{array}{l}\text { Urine } \\
\text { flow }\end{array}$} & \multirow[b]{2}{*}{$\begin{array}{l}\text { Urine } \\
\text { peni- } \\
\text { cillin }\end{array}$} & \multirow[b]{2}{*}{$\begin{array}{l}\text { Average } \\
\text { serum } \\
\text { penicillin }\end{array}$} & \multicolumn{2}{|c|}{$\begin{array}{l}\text { Renal clearance of } \\
\text { penicillin }\end{array}$} & \multicolumn{2}{|c|}{$\begin{array}{l}\text { Rate of glomerular } \\
\text { filtration }\end{array}$} & \multirow{2}{*}{$\begin{array}{l}\text { Ratio of } \\
\text { glomerular } \\
\text { filtration } \\
\text { to peni- } \\
\text { cillin- } \\
\text { clearance }\end{array}$} \\
\hline & & & & & & $\begin{array}{l}\text { Experi- } \\
\text { mental } \\
\quad \text { (Aver.) }\end{array}$ & $\begin{array}{l}\text { Calcu- } \\
\text { lated } \\
\text { from } \\
\text { surface } \\
\text { area }\end{array}$ & $\begin{array}{c}\text { Experi- } \\
\text { mentally } \\
\text { detd. } \\
\text { with } \\
\text { inulin }\end{array}$ & $\begin{array}{l}\text { Calcu- } \\
\text { lated } \\
\text { from } \\
\text { surface } \\
\text { area }\end{array}$ & \\
\hline \multirow{6}{*}{$\mathrm{X}$} & $\begin{array}{c}\mathrm{T} . \\
\mathrm{Wt} .=58 \mathrm{kgm} . \\
\text { Ht. }=66 \frac{1}{\mathrm{i}} \mathrm{in} . \\
\text { Surface area }= \\
1.66 \mathrm{sq} . \mathrm{m} .\end{array}$ & $\begin{array}{c}\text { hours } \\
\frac{1}{1-\frac{1}{2}} \\
\frac{1}{2}-1 \\
1-2\end{array}$ & $\begin{array}{c}\text { ml. per } \\
\text { min. } \\
18.8 \\
8.5 \\
2.3\end{array}$ & $\begin{array}{c}\text { Mg. per } \\
\text { min. } \\
579 \\
147 \\
40\end{array}$ & $\begin{array}{c}\text { Ag. per } \\
\text { ml. } \\
0.37 \\
0.22 \\
0.075\end{array}$ & $\begin{array}{l}1560 \\
668(920) \\
533\end{array}$ & $?$ & $\begin{array}{l}140 \\
144\end{array}$ & 126 & $\begin{array}{l}0.21 \\
0.27\end{array}$ \\
\hline & $\begin{array}{l}\mathrm{J} . \mathrm{W} . \\
\text { Wt. }=60.5 \mathrm{kgm} . \\
\text { Ht. }=67 \mathrm{in} . \\
\text { Surface area }= \\
1.68 \text { sq. } \mathrm{m} .\end{array}$ & $\begin{array}{l}0-1 \\
1-2\end{array}$ & & $\begin{array}{l}241 \\
202\end{array}$ & $\begin{array}{l}0.40 \\
0.20\end{array}$ & $\begin{array}{l}600(800) \\
1010\end{array}$ & 670 & & 126 & $\begin{array}{l}0.21 \\
0.13\end{array}$ \\
\hline & $\begin{array}{l}\text { R.W. } \\
\text { Wt. }=53 \mathrm{kgm} . \\
\text { Ht. }=64 \text { in. } \\
\text { Surface area }= \\
1.55 \text { sq. } \mathrm{m} .\end{array}$ & $\begin{array}{l}\frac{1}{2}-1 \\
1-2\end{array}$ & $\begin{array}{l}2.6 \\
6.5\end{array}$ & $\begin{array}{l}76.5 \\
27.9\end{array}$ & $\begin{array}{l}0.135 \\
0.054\end{array}$ & $\begin{array}{l}567 \\
517(540)\end{array}$ & 625 & - & 117 & $\begin{array}{l}0.21 \\
0.23\end{array}$ \\
\hline & $\begin{array}{l}\text { G. } \\
\text { W.t. }=75 \mathrm{kgm} . \\
\text { Ht. }=68 \mathrm{in} . \\
\text { Surface area }= \\
1.86 \mathrm{sq} . \mathrm{m} .\end{array}$ & $\begin{array}{l}\frac{3}{2}-\frac{1}{2} \\
\frac{1}{2}-1 \\
1-2\end{array}$ & $\begin{array}{r}15.9 \\
7.8 \\
4.1\end{array}$ & $\begin{array}{l}635 \\
169 \\
287\end{array}$ & $\begin{array}{l}0.45 \\
0.20 \\
0.084\end{array}$ & $\begin{array}{l}1410 ? \\
845(865) \\
342\end{array}$ & 750 & $\begin{array}{r}154 \\
154 \\
69\end{array}$ & 141 & $\begin{array}{l}0.11 ? \\
0.18 \\
0.20\end{array}$ \\
\hline & $\begin{array}{l}\text { B. H. } \\
\text { Wt. }=51 \mathrm{kgm} . \\
\text { Ht. }=64 \text { in. } \\
\text { Surface area }= \\
1.52 \text { sq. m. }\end{array}$ & $\begin{array}{l}1-2 \\
2-3 \\
3-4\end{array}$ & $\begin{array}{l}0.9 \\
2.7 \\
1.0\end{array}$ & $\begin{array}{r}188 \\
72 \\
19\end{array}$ & $\begin{array}{l}0.41 \\
0.14 \\
0.05\end{array}$ & $\begin{array}{l}460 \\
534(450) \\
366\end{array}$ & 453 & & 115 & $\begin{array}{l}0.25 \\
0.22 \\
0.31\end{array}$ \\
\hline & $\begin{array}{l}\text { S. } \\
\text { Wt. }=67 \mathrm{kgm} . \\
\text { Ht. }=69 \frac{1}{4} \text { in. } \\
\text { Surface area }= \\
1.82 \text { sq. m. }\end{array}$ & $\begin{array}{l}0-1 \\
1-2\end{array}$ & & $\begin{array}{l}410 \\
157\end{array}$ & $\begin{array}{l}0.60 \\
0.19\end{array}$ & $\begin{array}{l}700 \pm \\
826(760)\end{array}$ & 763 & & 137 & $\begin{array}{l}0.20 \\
0.17\end{array}$ \\
\hline
\end{tabular}

time for which penicillin remained at measurable levels precluded a precise measurement of the average blood level during the period of urine collection, and the figures in Table $\mathrm{V}$ with respect to the renal clearance of penicillin $\mathrm{K}$ are of dubious significance.

In an attempt to saturate the tubular secretory mechanism, rabbits were injected intravenously with 6,60 and $600 \mathrm{mgm}$. per $\mathrm{kgm}$. of penicillin $\mathrm{G}$, and blood and urine specimens were obtained for assay in the usual manner. As is shown in Table IV, after injection at 6 or $60 \mathrm{mgm}$. per $\mathrm{kgm}$. the renal clearance of penicillin remained at a high level which did not vary significantly over the entire range of plasma concentration studied, and approximated the total renal plasma flow. Saturation of the tubular excretory mechanism was, how- ever, achieved by a single intravenous injection of penicillin $\mathrm{G}$ at $600 \mathrm{mgm}$. per $\mathrm{kgm}$., which corresponds to 60 million units in the average human adult. As is shown in Table $\mathrm{V}$, in 2 rabbits so injected, with initial blood levels 5 to 7 minutes after the injection, of 2,667 and 3,200 micrograms per ml., the renal clearance of penicillin in the first hour after the injection was abnormally low (9.0, decreasing to $3 \mathrm{ml}$., in rabbit 5791, and $7 \mathrm{ml}$. per minute in rabbit 5939). These values are of the same order of magnitude as the normal rate of glomerular filtration reported by Walker and his associates (18). The renal clearance remained at this low level until the plasma concentration had fallen in 1 instance to approximately 1,500, and in the other to approximately $1,000 \mu \mathrm{g}$. Thereafter, the renal clearance rose, in 1 instance sharply, 
TABLE III

The renal clearance of penicillin $G$ in man after the intramuscular injection of a suspension in peanut oil and beeswax 300,000 units per ml. equals $180 \mathrm{mgm}$. per ml.

\begin{tabular}{|c|c|c|c|c|c|c|c|c|}
\hline \multirow{2}{*}{ Patient } & \multirow{2}{*}{ Penicillin dosage } & \multicolumn{2}{|c|}{ Urine collection } & \multirow{2}{*}{$\begin{array}{c}\text { Urine } \\
\text { penicillin }\end{array}$} & \multirow{2}{*}{$\begin{array}{c}\text { Average } \\
\text { penicillin } \\
\text { blood } \\
\text { level }\end{array}$} & \multirow{2}{*}{$\begin{array}{c}\text { Renal } \\
\text { clearance of } \\
\text { penicillin }\end{array}$} & \multirow{2}{*}{$\begin{array}{c}\text { Glomer- } \\
\text { ular } \\
\text { filtration } \\
\text { rate* }\end{array}$} & \multirow{2}{*}{$\begin{array}{l}\text { Ratio of } \\
\text { glomerular } \\
\text { filtration } \\
\text { to total } \\
\text { renal } \\
\text { clearance }\end{array}$} \\
\hline & & $\begin{array}{l}\text { Time } \\
\text { periods }\end{array}$ & $\begin{array}{l}\text { Urine. } \\
\text { flow }\end{array}$ & & & & & \\
\hline $\begin{array}{l}\text { A. K. } \\
\text { Ht. }=71 \frac{3}{\mathrm{in}} . \\
\text { Wt. }=79 \mathrm{kgm} . \\
\text { Surface area }= \\
2.0 \mathrm{sq} . \mathrm{m} .\end{array}$ & $\begin{array}{l}1 \mathrm{ml} .=2.3 \mathrm{mgm} . \\
\text { per kgm. } \\
\\
.\end{array}$ & $\begin{array}{c}\text { minutes } \\
35-56 \\
56-77 \\
77-104 \\
104-166 \\
166-185 \\
185-391\end{array}$ & $\begin{array}{c}\text { ml. per } \\
\text { min. } \\
1.0 \\
2.1 \\
2.5 \\
1.6 \\
1.5 \\
0.7\end{array}$ & $\begin{array}{c}\text { ug. per } \\
\text { min. } \\
213 \\
309 \\
245 \\
476 \\
1010 \\
311 ?\end{array}$ & $\begin{array}{l}0.36 \\
0.40 \\
0.42 \\
0.60 \\
0.92 \\
1.10\end{array}$ & $\begin{array}{c}\text { ml. per min. } \\
592 \\
772 \\
583 \\
793 \\
1097 \\
283 \\
\text { Experi- } \\
\text { mental } \\
\text { average } 687 \\
\text { Calcd. } \\
\text { from sur- } \\
\text { face area } 796\end{array}$ & $\begin{array}{l}168 \\
150\end{array}$ & $\begin{array}{l}0.23 \\
0.24 \\
0.32\end{array}$ \\
\hline $\begin{array}{l}\text { S. C. } \\
\text { Ht. }=65 \frac{1}{2} \text { in. } \\
\text { Wt. }=52 \mathrm{kgm} . \\
\text { Surface area }= \\
1.57 \text { sq. } \mathrm{m} .\end{array}$ & $\begin{array}{l}0.9 \mathrm{ml} .=3.1 \mathrm{mgm} . \\
\text { per kgm. }\end{array}$ & $\begin{array}{c}37-56 \\
56-78 \\
78-96 \\
96-118 \\
118-145 \\
145-240\end{array}$ & $\begin{array}{l}1.6 \\
1.4 \\
2.1 \\
2.6 \\
2.8 \\
1.2\end{array}$ & $\begin{array}{l}361 \\
364 \\
507 \\
383 \\
383 \\
508\end{array}$ & $\begin{array}{l}0.65 \\
0.76 \\
0.90 \\
1.00 \\
1.00 \\
1.10\end{array}$ & $\begin{array}{c}555 \\
479 \\
563 \\
383 \\
383 \\
462 \\
\text { Experi- } \\
\text { mental } \\
\text { average } \quad 471 \\
\text { Calcd. } \\
\text { from sur- } \\
\text { face area } 632\end{array}$ & $\begin{array}{r}150 \\
112 \\
145 \\
111 \\
99\end{array}$ & $\begin{array}{l}0.27 \\
0.24 \\
0.26 \\
0.29 \\
0.26\end{array}$ \\
\hline
\end{tabular}

* Experimentally determined with sodium thiosulfate.

and in 1 progressively, to reach peak values of 18 to 28 and 23 to $57 \mathrm{ml}$. per minute. As is shown in Figure 4, the rate at which penicillin G disappeared from the blood of these 2 rabbits paralleled its renal clearance. During the phase of tubular saturation, the blood level fell slowly; but as the renal clearance increased toward normal levels there was a parallel accelerating drop in the serum concentration, particularly evident in rabbit 5791 .

In the latter rabbit the glomerular filtration rate and renal plasma had been determined experimentally with sodium thiosulfate and para-aminohippuric acid, 2 days before the injection of the penicillin. The observed glomerular filtration rates of 6.0 and $6.4 \mathrm{ml}$. per minute agree with the renal clearance of penicillin during the period of tubular saturation ( 3 to $9 \mathrm{ml}$.) ; while the paraaminohippuric acid clearances of 17.5 and $18.0 \mathrm{ml}$. per minute are in reasonably good agreement with the penicillin clearances of 18 to $28 \mathrm{ml}$. per minute, obtained when the plasma levels had fallen below the level of tubular saturation.

The results in a number of rabbits' experiments in which the animals received varying amounts of commercial sodium penicillin (of unknown composition with respect to penicillins $F, G, K$, and $X)$, given as a single injection, are summarized in Table $\mathrm{V}$. In 7 rabbits injected at dosages of $4,000,8 ; 000$, or 150,000 units per kgm., the average renal clearances were $53,57,40,28,42,24$, and $43 \mathrm{ml}$. per minute. In these experiments the blood level varied from a peak of $45 \mu \mathrm{g}$. per $\mathrm{ml}$. to a low of $0.044 \mu \mathrm{g}$.

In rabbit 5660 , injected with commercial penicillin at 1,200,000 units per kgm., the renal clearance was abnormally low, with observed values of $10,13,5.7$, and $4.9 \mathrm{ml}$. per minute in successive time periods. As had previously been found with penicillin $G$, the tubular secretory mechanism had been saturated by the high blood levels, which in this animal ranged from 580 to $800 \mu \mathrm{g}$. per $\mathrm{ml}$. 
DISCUSSION

1. The data here presented indicate that in both rabbits and man, penicillins $F, G$, and $X$ are secreted into the urine by the kidney at a rate which corresponds essentially to their total removal from the blood reaching that organ. The normal renal clearance of penicillin so closely approximates the renal plasma flow as determined experimentally with para-aminohippuric acid that it may be used as a test of kidney function. Indeed, penicillin has

TABLE IV

The renal clearance of penicillins $F, G, K$ and $X$ in rabbits

Single intramuscular injection

\begin{tabular}{|c|c|c|c|c|c|c|c|}
\hline $\begin{array}{c}\text { Penicillin } \\
\text { species }\end{array}$ & $\begin{array}{c}\text { Rabbit } \\
\text { no. }\end{array}$ & Weight & $\begin{array}{c}\text { Penicillin } \\
\text { dosage }\end{array}$ & $\begin{array}{l}\text { Time of urine } \\
\text { collection }\end{array}$ & $\begin{array}{l}\text { Urine } \\
\text { penicillin }\end{array}$ & $\begin{array}{l}\text { Average serum } \\
\text { penicillin }\end{array}$ & $\begin{array}{l}\text { Renal clearance } \\
\text { of penicillin }\end{array}$ \\
\hline \multirow{4}{*}{$\mathbf{F}$} & 5244 & 2.25 & $\begin{array}{c}\text { mgm. per kgm. } \\
0.35\end{array}$ & $\begin{array}{c}\text { hours } \\
0-1\end{array}$ & $\begin{array}{c}\text { Mg. per ml. } \\
7.7\end{array}$ & $\begin{array}{c}\text { Mg. per ml. } \\
0.25\end{array}$ & $\begin{array}{l}\text { ml. per min. } \\
31\end{array}$ \\
\hline & 5245 & 2.5 & 0.6 & $\begin{array}{l}0-1 \\
1-2\end{array}$ & $\begin{array}{r}14.3 \\
2.5\end{array}$ & $\begin{array}{l}0.42 \\
0.063\end{array}$ & $\left.\begin{array}{l}34 \\
40\end{array}\right\}(37)$ \\
\hline & 5296 & 2.22 & 0.6 & $\begin{array}{l}0-1 \\
1-2\end{array}$ & $\begin{array}{l}8.6 \\
0.86\end{array}$ & $\begin{array}{l}0.4 \\
0.1\end{array}$ & $\begin{array}{l}22 \\
8.6\end{array}$ \\
\hline & 5446 & 3.14 & 0.6 & $\frac{1}{2}-1$ & 6.9 & 0.15 & 46 \\
\hline \multirow{10}{*}{ G } & 5318 & 2.72 & 0.6 & $0-1$ & 30 & 0.27 & 111 \\
\hline & 5428 & 2.73 & 0.6 & $\frac{1}{1-1}$ & $\begin{array}{c}10.5 \\
2.83\end{array}$ & $\begin{array}{l}0.38 \\
0.14\end{array}$ & $\left.\begin{array}{l}28 \\
20\end{array}\right\}(24)$ \\
\hline & 5445 & 3.08 & 0.6 & $\begin{array}{l}1-1 \\
1-2 \\
2-3\end{array}$ & $\begin{array}{c}10 \\
5.75 \\
3.8 \\
\end{array}$ & $\begin{array}{l}0.18 \\
0.11 \\
0.07\end{array}$ & $\left.\begin{array}{l}55 \\
52 \\
54\end{array}\right\}(54)$ \\
\hline & 5467 & 2.8 & 0.6 & $\begin{array}{l}\frac{1}{2}-1 \\
1-2\end{array}$ & $\begin{array}{c}12.3 \\
3\end{array}$ & $\begin{array}{l}0.2 \\
0.038 \\
\end{array}$ & $\left.\begin{array}{l}62 \\
79\end{array}\right\}(70)$ \\
\hline & 5159 & 2.37 & 1.5 & $1-2$ & 23 & 0.42 & 55 \\
\hline & 5187 & 2.24 & 1.5 & $1-2$ & 14.7 & 0.85 & 17 \\
\hline & 5843 & 2.74 & 6 & $\begin{array}{l}\frac{1}{12}-\frac{1}{2} \\
\frac{1}{2}+\frac{1}{2} \\
\frac{1}{2}-1 \\
1-2 \\
1-2\end{array}$ & $\begin{array}{c}1,170 \\
384 \\
90.5 \\
21.6\end{array}$ & $\begin{array}{l}11 \\
3.1 \\
1.3 \\
0.25\end{array}$ & $\left.\begin{array}{r}106 \\
124 \\
69 \\
86\end{array}\right\}(96)$ \\
\hline & 5823 & 2.48 & 60 & $\begin{array}{l}0-1 \\
1-2 \\
2-4 \\
4-6\end{array}$ & $\begin{array}{c}1,813 \\
249 \\
66.7 \\
7.5\end{array}$ & $\begin{array}{l}20 \\
6.3 \\
2.65 \\
0.35\end{array}$ & $\left.\begin{array}{l}91 \\
39 \\
25 \\
21\end{array}\right\}(44)$ \\
\hline & $5791^{*}$ & 2.44 & 600 & $\begin{array}{c}7 \min _{1-}-\frac{1}{1} \\
\frac{1}{2}-1 \\
\frac{1}{2}-1 \\
1-2 \\
2-4 \\
4-6 \\
6-8 \\
8-10 \\
10-12 \\
12-13 \frac{1}{2}\end{array}$ & $\begin{array}{c}20,800 \\
13,050 \\
4,630 \\
5,000 \\
2,338 \\
452 \\
58 \\
40.8 \\
27.8 \\
21.3 \\
\end{array}$ & $\begin{array}{c}2,300 \\
1,800 \\
1,560 \\
1,500 \\
130 \\
5.2 \\
2.6 \\
1.8 \\
1.0 \\
. \quad 0.92 \\
\end{array}$ & $\begin{array}{c}9.0 \\
7.3 \\
3.0 \\
3.3 \\
18 \\
90 \\
22 \\
22 \\
28 \\
23 \\
\end{array}$ \\
\hline & $5939 \dagger$ & 2.82 & 600 & $\begin{array}{l}\text { 0-36 min. } \\
36-66 \mathrm{~min} . \\
\text { 66-106 min. } \\
106-136 \mathrm{~min} . \\
136-166 \mathrm{~min} . \\
166-199 \mathrm{~min} . \\
199-232 \mathrm{~min} . \\
232-262 \mathrm{~min} .\end{array}$ & $\begin{array}{r}16,667 \\
7,310 \\
8,890 \\
2,600 \\
1,891 \\
931 \\
415 \\
320\end{array}$ & $\begin{array}{c}2,400 \\
1,050 \\
350 \\
110 \\
40 \\
16.3 \\
10 \\
6.7\end{array}$ & $\begin{array}{l}6.9 \\
7.0 \\
23 \\
24 \\
47 \\
57 \\
42 \\
48\end{array}$ \\
\hline
\end{tabular}


TABLE IV-Continued

\begin{tabular}{|c|c|c|c|c|c|c|c|}
\hline $\begin{array}{l}\text { Penicillin } \\
\text { species }\end{array}$ & $\begin{array}{c}\text { Rabbit } \\
\text { no. }\end{array}$ & Weight & $\begin{array}{l}\text { Penicillin } \\
\text { dosage }\end{array}$ & $\begin{array}{l}\text { Time of urine } \\
\text { collection }\end{array}$ & $\begin{array}{c}\text { Urine } \\
\text { penicillin }\end{array}$ & $\begin{array}{c}\text { Average serum } \\
\text { penicillin }\end{array}$ & $\begin{array}{l}\text { Renal clearance } \\
\text { of penicilllin. }\end{array}$ \\
\hline \multirow{5}{*}{$\mathbf{K}$} & 5186 & 2.73 & $\begin{array}{c}m g m . \text { per kgm. } \\
0.6\end{array}$ & $\begin{array}{l}\text { hours } \\
0-1\end{array}$ & $\begin{array}{r}\text { Mg. per } m l . \\
8.15\end{array}$ & $\begin{array}{c}\text { Mg. per ml. } \\
0.3 \pm\end{array}$ & $\begin{array}{c}m l . \text { per min. } \\
27\end{array}$ \\
\hline & 5210 & 2.23 & 0.6 & $0-1$ & 12.3 & $0.12 \pm$ & 100 \\
\hline & 5242 & 3.16 & 0.6 & $0-1$ & 10.1 & $0.35 ?$ & 29 \\
\hline & 5319 & 3.09 & 0.6 & $0-1$ & 8.8 & $0.17 \pm$ & 52 \\
\hline & 5447 & 2.93 & 0.6 & $0-\frac{1}{2}$ & 9.0 & $0.22 \pm$ & 41 \\
\hline \multirow{5}{*}{$\mathbf{x}$} & 5252 & 2.35 & 0.6 & $1-2$ & 2.9 & 0.115 & 25 \\
\hline & 5258 & 2.11 & 0.6 & $1-2$ & 3.6 & 0.09 & 40 \\
\hline & 5327 & 2.85 & 0.6 & $1-2$ & 5.7 & 0.16 & 36 \\
\hline & 5449 & 3.03 & 0.6 & $\begin{array}{l}\frac{1}{2}-1 \\
1-2 \\
2-3\end{array}$ & $\begin{array}{l}18.3 \\
5.6 \\
1.66\end{array}$ & $\begin{array}{l}0.265 \\
0.11 \\
0.04\end{array}$ & $\left.\begin{array}{l}69 \\
51 \\
42\end{array}\right\}(54)$ \\
\hline & 5465 & 2.8 & 0.6 & $\begin{array}{l}1-1 \\
1-2 \\
2-3\end{array}$ & $\begin{array}{l}2.7(?)^{*} \\
2.7 \\
1.75\end{array}$ & $\begin{array}{l}0.165 \\
0.095 \\
0.07\end{array}$ & $\left.\begin{array}{l}17(?) \\
28 \\
25\end{array}\right\}(23)$ \\
\hline
\end{tabular}

* Injected intravenously instead of intramuscularly.

$\dagger$ Average value questionable because of rapidly changing blood level in this period.

certain unique points of superiority over diodrast, para-aminohippuric acid, or any other substance currently used for that purpose. The plasma concentrations of the latter compounds cannot exceed a level of 3 to $5 \mathrm{mgm}$. per cent, as higher concentrations may so overload the tubular mechanism responsible for their secretion that complete extraction does not take place. On the other hand, plasma concentrations much lower than $1 \mathrm{mgm}$. per cent do not permit accurate determinations by the usual laboratory methods. In consequence, the useful range of plasma concentration varies only 5fold. With penicillin, however, because the biological method used for assay is sensitive to as little as 1 part in $80,000,000$ (0.00125 mgm. per cent), and because complete renal clearance is observed up to a minimum level of $1 \mathrm{mgm}$. per cent in man $(10 \mu \mathrm{g}$. per ml.), and in rabbits of at least $4 \mathrm{mgm}$. per cent, there is as least a 1,000 -fold range of plasma concentration within which the renal clearance of penicillin can be used as a measure of renal function in man.

2. The low renal clearance of penicillin $K$ in man, approximately $1 / 2$ to $1 / 5$ that of penicillins $F$, $\mathrm{G}$, or $\mathrm{X}$, would at first sight imply that penicillin $\mathrm{K}$ is excreted more slowly than the other species.
This should be reflected in a more sustained blood level. Instead, previous work in this and other laboratories ( 2 to 4 ) has shown that penicillin $\mathrm{K}$ disappears from the blood more rapidly than do the other penicillins. Moreover, the total urinary excretion in man has been shown to average only 30 per cent of the amount injected, as compared with recoveries for $G$ and $X$ of 80 to 100 per cent. The contradictions involved in a low renal clearance, a rapidly falling blood level, and a low urinary recovery may be more apparent than real. The low urinary recovery of penicillin $\mathrm{K}$, and its rapid disappearance from the blood are probably referable to the fact that it is bound and inactivated by both the plasma $(14,20)$ and tissues $(21,22,23)$ to a greater extent than is e.g. penicillin G. That combination with plasma protein may be not only quantitatively more complete, but also less freely reversible, and thus prevent the complete removal of penicillin $\mathrm{K}$ from the blood by the renal secretory mechanism.

3. The fact that penicillins $F, G$, and $X$ have a renal clearance approximating the total plasma flow through the kidney is reflected in the rapidly falling blood levels observed after their intravenous or intramuscular injection in aqueous solution. 
Attempts to modify the rate of excretion by reducing the rate of urine flow, as by restricting salt and water intake, or by administering pitressin, are physiologically unsound. As is true of other substances with maximal tubular secretion, the renal clearance of penicillin has been shown to be unaffected even by wide variations in the rate of urine flow. Such measures could modify the rate of secretion only by affecting the blood flow to the kidney.

A second suggested method of delaying the excretion of penicillin is to block its excretion by the administration of other substances excreted by the same tubular mechanism. Diodrast, para-aminohippuric acid and benzoic acid ( 5 to 10,12$)$ have all been reported as effective in this respect. The difficulty lies in the fact that these blocking substances are as rapidly excreted as the penicillin itself. To maintain an effective concentration of such blocking agents may prove no less laborious, and with some of these agents, no less costly, than

\section{TABLE V}

The renal clearance of penicillin in rabbits

Single intramuscular injection of commercial sodium salt

\begin{tabular}{|c|c|c|c|c|c|c|}
\hline $\begin{array}{c}\text { Rab- } \\
\text { bit } \\
\text { no. }\end{array}$ & Weight & $\begin{array}{c}\text { Penicillin } \\
\text { dosage }\end{array}$ & $\begin{array}{c}\text { Time of } \\
\text { urine } \\
\text { collec- } \\
\text { tion }\end{array}$ & $\begin{array}{c}\text { Urine } \\
\text { penicillin }\end{array}$ & $\begin{array}{c}\text { Average } \\
\text { serum } \\
\text { peni- } \\
\text { cillin }\end{array}$ & $\begin{array}{l}\text { Renal } \\
\text { clearance } \\
\text { of peni- } \\
\text { cillin }\end{array}$ \\
\hline 3851 & $\begin{array}{l}\mathrm{kgm} . \\
2.5\end{array}$ & $\begin{array}{l}\text { units per } \\
\text { kgm. } \\
4,000\end{array}$ & $\begin{array}{c}\text { hours } \\
1-2 \\
2-3\end{array}$ & $\begin{array}{c}\text { units per } \\
\text { min. } \\
8.55 \\
2.3\end{array}$ & $\begin{array}{c}\text { units per } \\
\text { ml. } \\
0.16 \\
0.044\end{array}$ & $\left.\begin{array}{c}\text { ml. per } \\
\text { min. } \\
53 \\
52\end{array}\right\} 53$ \\
\hline 3925 & 2.8 & 4,000 & $\begin{array}{l}1-2 \\
2-3\end{array}$ & $\begin{array}{r}12.4 \\
4.5\end{array}$ & $\begin{array}{l}0.28 \\
0.065\end{array}$ & $\left.\begin{array}{l}44 \\
69\end{array}\right\} 57$ \\
\hline 4100 & 2.64 & 8,000 & $\begin{array}{l}1-2 \\
2-3\end{array}$ & $\begin{array}{r}38.1 \\
6.9\end{array}$ & $\begin{array}{l}1.05 \\
0.16\end{array}$ & $\left.\begin{array}{l}36 \\
43\end{array}\right\} 40$ \\
\hline 4157 & 2.62 & 8,000 & $\begin{array}{l}1-2 \\
2-3 \\
3-4\end{array}$ & $\begin{array}{c}20.5 \\
6.7 \\
0.78\end{array}$ & $\begin{array}{l}1.0 \\
0.18 \\
0.03\end{array}$ & $\left.\begin{array}{l}21 \\
37 \\
26\end{array}\right\} 28$ \\
\hline 4132 & 2.43 & 8,000 & $1-2$ & 41.5 & 1.0 & 42 \\
\hline 4158 & 2.32 & 8,000 & $1-2$ & 7.1 & 0.3 & 24 \\
\hline 5961 & 3.7 & 150,000 & $\begin{array}{l}\frac{1}{2}-\frac{1}{2} \\
\frac{3}{2}-1 \\
1-2 \\
2-3 \\
3-4\end{array}$ & $\begin{array}{r}1,408 \\
2,432 \\
1,360 \\
737 \\
596\end{array}$ & $\begin{array}{l}43 \\
45 \\
34 \\
19 \\
13\end{array}$ & $\left.\begin{array}{l}33 \\
54 \\
40 \\
39 \\
46\end{array}\right\} 43$ \\
\hline 5660 & 2.7 & $1,200,000$ & $\begin{array}{l}1-\frac{1}{2} \\
1-1 \\
1-2 \\
2-3\end{array}$ & $\begin{array}{l}5,713 \\
9,856 \\
4,576 \\
3,422\end{array}$ & $\begin{array}{l}580 \\
770 \\
800 \\
700\end{array}$ & $\left.\begin{array}{c}10 \\
13 \\
5.7 \\
4.9\end{array}\right\} 8.4$ \\
\hline
\end{tabular}

to repeat the injections of penicillin or to increase the dosage.

The most effective method yet suggested of prolonging the time for which penicillins $F, G$, and $X$ remain in the blood at effective concentrations is to delay its absorption from an intramuscular depot. This has been accomplished by injecting the drug as a suspension in peanut oil and beeswax (15). The absorption then proceeds at a slower rate than the excretion, and the time for which the penicillin remains in the blood in demonstrable and effectively bactericidal concentrations is significantly prolonged.

4. It is clear from the data here reported that the therapeutic efficacy of penicillin would be greatly enhanced were it possible by appropriate chemical modification to decrease its renal clearance. An antibiotic with the same bactericidal activity as

TABLE VI

The renal clearance of penicillins $F, G, K$, and $X$ in man and in rabbits

Summary of all experiments

\begin{tabular}{|c|c|c|c|c|c|c|}
\hline \multirow{4}{*}{$\begin{array}{l}\text { Penicillin } \\
\text { species }\end{array}$} & \multicolumn{6}{|c|}{ Renal clearance, ml. per minute } \\
\hline & \multicolumn{4}{|c|}{ Man } & \multicolumn{2}{|l|}{ Rabbit } \\
\hline & \multicolumn{3}{|c|}{ Observed clearances } & \multirow[b]{2}{*}{$\begin{array}{c}\text { Mean } \\
\text { of } \\
\text { all } \\
\text { expts. }\end{array}$} & \multirow[b]{2}{*}{$\begin{array}{l}\text { Observed } \\
\text { clearances }\end{array}$} & \multirow[b]{2}{*}{ Mean } \\
\hline & $\begin{array}{l}\text { Contin- } \\
\text { uous } \\
\text { infu- } \\
\text { sion }\end{array}$ & $\begin{array}{c}\text { Single } \\
\text { injec- } \\
\text { tion, } \\
\text { aque- } \\
\text { ous }\end{array}$ & $\begin{array}{c}\text { Single } \\
\text { injec- } \\
\text { tion, } \\
\text { POB }\end{array}$ & & & \\
\hline $\mathbf{F}$ & $\begin{array}{l}550 \\
900\end{array}$ & & & 725 & $\begin{array}{l}31,37,15 \\
46\end{array}$ & 32 \\
\hline $\mathbf{G}$ & 525 & $\begin{array}{l}335 \\
850\end{array}$ & $\begin{array}{l}687 \\
409\end{array}$ & 560 & $\begin{array}{l}111,24,54 \\
70,55,18 \\
96,44,24 \\
65\end{array}$ & 56 \\
\hline $\mathbf{K}$ & $\begin{array}{l}272 \\
269\end{array}$ & $\begin{array}{l}225 \\
188 \\
627 \\
375 \\
165\end{array}$ & & 300 & & \\
\hline $\mathbf{X}$ & 652 & $\begin{array}{l}920 \\
800 \\
542 \\
865 \\
450 \\
763\end{array}$ & & 710 & $\begin{array}{l}26,40,36 \\
54,23\end{array}$ & 36 \\
\hline $\begin{array}{l}\text { Commercial } \\
\text { penicillin }\end{array}$ & & & & & $\begin{array}{l}53,57,40 \\
28,42,24 \\
43\end{array}$ & 41 \\
\hline
\end{tabular}




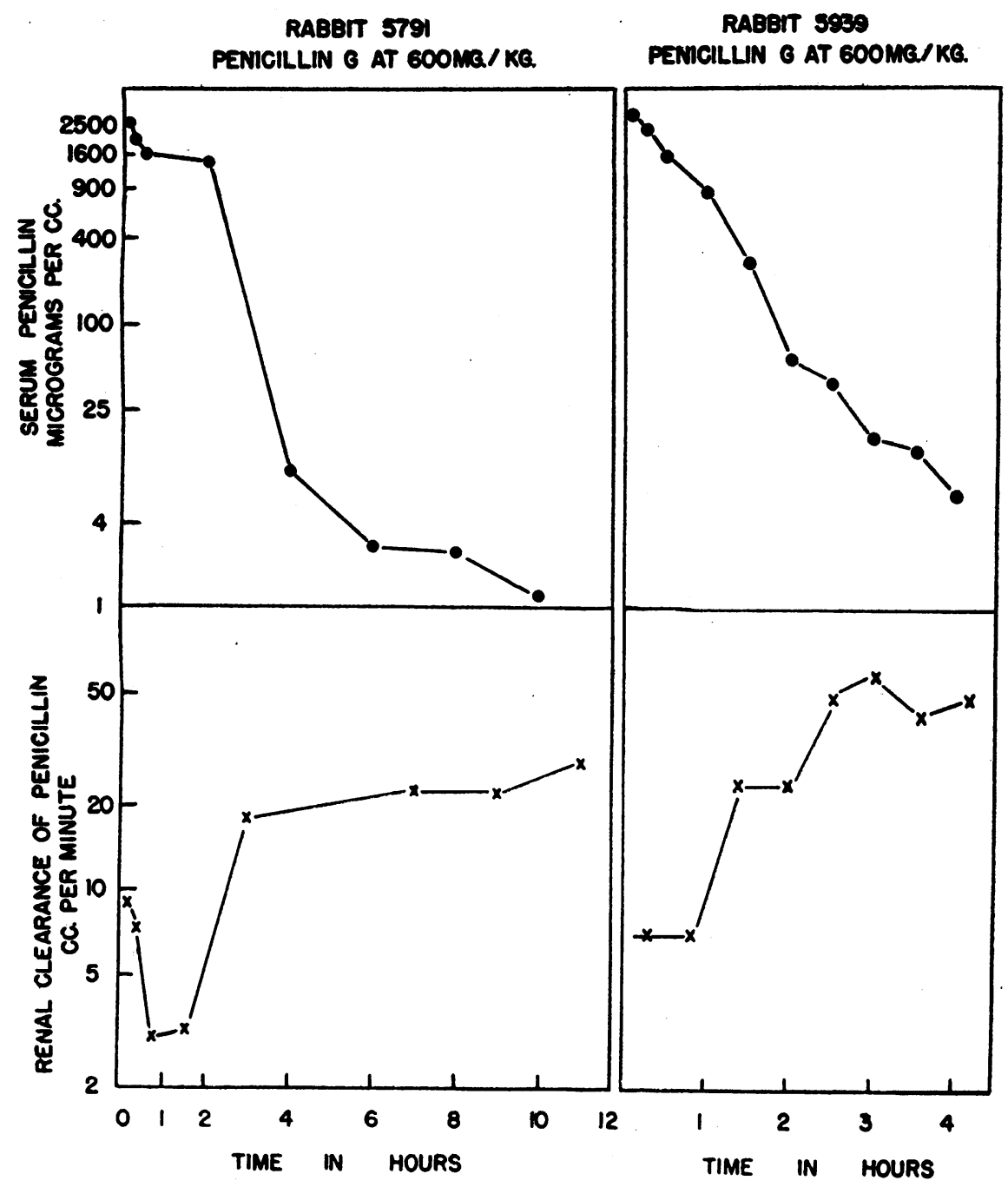

Fig. 4. The Saturation of the Renal Secretory Mechanism for Penicillin G by a Single Massive Intravenous Dose of 600 Mgm. Per Kgm.

penicillin in vitro, but with a renal clearance in man of e.g., 150 instead of $600 \mathrm{ml}$. per minute, might well be many times more active, since both the serum concentration of penicillin and the time for which an effective level was maintained would thereby be increased. The present experiments with $F, G$, and $X$ indicate that the groupings present in these 3 species have no demonstrable effect on the rate of tubular secretion; and the apparently lower renal clearance of $K$ is more than counteracted by some of its other pharmacological properties. It is nevertheless possible that derivatives of penicillin produced either by direct chem- ical modification or by the addition of appropriate precursors to the culture medium may have a significantly lower renal clearance than the 4 natural penicillins here studied, and a correspondingly enhanced therapeutic activity.

\section{SUMMARY}

1. The renal clearance of penicillins $F, G$, and $X$ in man was found to approximate the total renal plasma flow and was approximately 4 to 5 times greater than the renal clearance of inulin or sodium thiosulfate. The penicillin clearance was independent of the absolute blood level over the entire 
range 0.05 to $10 \mu \mathrm{g}$. per $\mathrm{ml}$. and was similarly independent of the rate of urine flow.

2. The possibility is suggested that penicillin can be used in lieu of para-aminohippuric acid or diodrast as a test of renal plasma flow and renal function.

3. The renal clearance of penicillin $K$ in man varied from $1 / 4$ to $1 / 2$ that of $F, G$, or $X$. Possible explanations for this anomalous result are discussed in the text.

4. The tubular excretory mechanism was completely saturated in 2 rabbits receiving $600 \mathrm{mgm}$. per $\mathrm{kgm}$. of penicillin $\mathrm{G}$. In these the initial blood levels were 2,667 and $3,200 \mu \mathrm{g}$.; and the initial renal clearances of 3 and $7 \mathrm{ml}$. per minute corresponded to the glomerular filtration rate. As the serum concentration fell to less than the saturation level for the tubular mechanism, the renal clearances rose to normal levels of 18 to 28 and 23 to $57 \mathrm{ml}$. per minute.

5. Although no differences were found between the renal clearance of penicillins $F, G$, or $X$, the possibility is suggested that penicillin derivatives may be produced with significantly lower clearances than those of the natural penicillins so far identified, and with correspondingly enhanced therapeutic activity in vivo.

\section{BIBLIOGRAPHY}

1. Rantz, L. A., and Kirby, W. M. M., Absorption and excretion of penicillin following continuous intravenous and subcutaneous administration. J. Clin. Invest., 1944, 23, 789.

2. Eagle, H., and Musselman, A. D., The low therapeutic activity of penicillin $K$ relative to that of penicillins $\mathrm{F}, \mathrm{G}$, and $\mathrm{X}$, and its pharmacological basis. Science, 1946, 103, 618.

3. Coghill, R. D., Osterberg, A. E., and Hazel, G. R., The relative effectiveness of pure penicillins $G$, X, and K. Science, 1946, 103, 709.

4. Eagle, H., The varying blood levels afforded by penicillins $F, G, K$, and $X$ in rabbits and man. $J$. Exp. Med., 1947, 85, 163.

5. Beyer, K. H., Woodward, F., Peters, L., Verwey, W. F., and Mattis, P. A., Prolongation of penicillin retention in body by means of para-aminohippuric acid. Science, 1944, 100, 107.

6. Beyer, K. H., Flippin, H., Verwey, W. F., and Woodward, R., Effect of para-aminohippuric acid on the plasma concentration of penicillin in man. J. A. M. A., 1944, 126, 1007.

7. Beyer, K. H., Peters, L., Woodward, R., and Verwey, W. F., Enhancement of the physiological economy of penicillin in dogs by the simultaneous adminisstration of para-aminohippuric acid. II. J. Pharmacol. \& Exper. Therap., 1944, 82, 310.

8. Beyer, K. H., Verwey, W. F., Woodward, R., Peters, L., and Mattis, P., The enhancement of the plasma concentration of penicillin in dogs by the simultaneous administration of para-aminohippuric acid. III. Am. J. M. Sc. 1945, 209, 608.

9. Loewe, L., Rosenblatt, P., Alture-Werber, E., and Kozak, M., Prolonging action of penicillin by paraaminohippuric acid. Proc. Soc. Exper. Biol. and Med., 1945, 58, 298.

10. Rammelkamp, C. H., and Bradley, S. E., Excretion of penicillin in man. Proc. Soc. Exper. Biol. \& Med., 1943, 53, 30.

11. Bronfenbrenner, J., and Favour, C. B., Increasing and prolonging blood penicillin concentrations following intramuscular administration. Science, 1945, $101,673$.

12. Moehlig, R. C., and Linkner, L. S., Penicillin with pitressin tannate for delaying excretory loss; preliminary report. Harper Hosp. Bull., 1945, 3, 73.

13. Eagle, $H$., Relative activity of penicillins $F, G, K$, and $\mathrm{X}$ against spirochetes and streptococci in vitro. J. Bact., 1946, 52, 81.

14. Eagle, $H$., The inactivation of penicillins $F, G, K$, and $\mathrm{X}$ by human and rabbit serum. J. Exp. Med., 1947, 85, 141.

15. Romansky, M. J., and Rittman, G. E., Penicillin: 1. Prolonged action in beeswax-peanut oil mixture. 2 . Single injection treatment of gonorrhea. Bull. U. S. Army M. Dept., 1944, 81, 43.

16. Goldring, W., and Chasis, $\mathrm{H}$., Hypertension and $\mathrm{Hy}-$ pertensive disease. The Commonwealth Fund, New York, 1944.

17. Newman, E. V., Gilman, A., and Philips, F. A., The renal clearance of thiosulfate in man. Bull. Johns Hopkins Hosp., Sept. 1946, in press.

18. Walker, A. M., Schmidt, C. F., Elsom, K. A., and Johnston, C. G., Renal blood flow of unanesthetized rabbits and dogs in diuresis and antidiuresis. Am. J. Physiol., 1937, 118, 95.

19. Tucker, H. A., and Eagle, H., The serum concentrations of Penicillin $\mathrm{G}$ in man following its intramuscular injection in aqueous solution and in peanut oil-beeswax suspension. In press.

20. Tompsett, R., Shultz, S., and McDermott, W., The relation of protein binding to the pharmacology and antibacterial activity of penicillins X, G, Dihydro F, and K. J. Bact., 1947, 53, 581.

21. Richardson, A. P., Miller, I., Schumacher, C., Jambor, W., Pansy, F., and Lapedes, D., Physiological disposition of penicillin $\mathrm{G}$ and $\mathrm{K}$ in dogs. Proc. Soc. Exper. Biol. and Med., 1946, 63, 514.

22. Tepperman, J., Rakieten, N., Valley, G., and Lyon, E. W., Inactivation of penicillins $\mathrm{G}$ and $\mathrm{K}$ by liver and kidney. Science, 1947, 105, 18.

23. Clowes, G. H. A., and Keltch, A. K., On comparative results obtained with crystalline penicillins $\mathrm{K}, \mathrm{G}$, 
$\mathrm{F}$, and $\mathrm{X}$ when exposed in the Warburg apparatus to the action of liver and other mammalian tissues, blood and blood fractions, and bacteria. Reported at Antibiotics Study Section Meeting, Washington, D.C., January 31 and February 1, 1947; Supplementary report on the comparative results obtained with crystalline penicillins, particularly $\mathrm{G}$ and $\mathrm{K}$, when exposed in the Warburg apparatus to the action of normal and preheated rat liver slices, homogenized liver, and bacteria; also notmal liver with enzyme-suppressing chemical agents. Reported at Antibiotics Study Section Meeting, Washington, D.C., January 31 and February 1, 1947.

24. Jensen, K. A., Moller, K. O., and Overgaard, K. Studies on the excretion of penicillin through the kidneys and the mechanism of this process. Acta Pharmacol. et Toxicolog., 1945, 1, 184. 